\title{
Integration Model of Conservation Values in The Subject of Study in The UNNES Faculty of Engineering to Support The Vision of Conservation Knowledge And International Reputation
}

\author{
Henry Ananta $^{1}$, Eko Supraptono $^{2}$, I Made Sudana $^{3}$, Riska Dami Ristanto $^{4}$ \\ \{henryananta@gmail.com ${ }^{1}$, ekosupraptono@mail.unnes.ac.id ${ }^{2}$, sudana@mail.unnes.ac.id ${ }^{3}$, \\ rdristanto@mail.unnes.ac.id ${ }^{4}$ \} \\ Universitas Negeri Semarang, Kampus Sekaran Gunungpati Kota Semarang Indonesia ${ }^{1,2,3,4}$
}

\begin{abstract}
The purpose of this research is to explore the conservation values that are most suitable for lectures in fields of study that support the university's vision. This research uses a quantitative approach, which measures the Integration of Conservation Values Model into the Field of Study at the Faculty of Engineering, UNNES.Conclusion; 1). Conservation values contained in concrete character conservation activities, the internalization process of conservation learning, lecture integration, and long-term vision can be applied in lectures in fields of study that support the university's vision. 2). Conservation values that are most suitable for lectures in the field of study that support the university's vision are the application of a long-term vision.
\end{abstract}

Keywords: Conservation values, integration, the vision of UNNES

\section{Introduction}

The constitution states that one of the Indonesian state government's objectives, which was carried out by the struggle for the Indonesian independence movement, is to promote the general welfare and educate the nation's life. Educational orientation is the development of quality education with one of the Sustainable Development Goals (SDGs) to encourage the welfare of all groups (Kemenristek Dikti, 2019).

One of the steps taken includes building quality human resources for young and adult people to have relevant knowledge and skills, including technical and vocational skills, to realize competitive, innovative, and human character resources. This theme is relevant in dealing with world conditions becoming increasingly sophisticated at an increasingly rapid pace of change. The software revolution has transformed economic activity, with some jobs requiring the education system to evolve accordingly.

Higher education is required to produce graduates who have adaptable, critical, creative, and innovative abilities. Starting from the above opinion, the General Course (MKU) of Conservation Education, which is implemented at UNNES, is a teaching material that supports the achievement of the university's vision, namely the University with Conservation Knowledge and International Standard. Philosophically, the study of conservation education means that the UNNES academic community is a living creature who is obliged to be responsible for 
preserving and developing culture, superior civilization, environmental preservation towards balance and order (Amin Retnoningsih, 2017: 34)

The integration of conservation values into subjects in the field of study within the Faculty of Engineering UNNES is an urgent and relevant need when the university has the desire to establish and establish itself as a university with conservation insight and international reputation. Therefore, it is natural and logical that the various subjects taught need to relate these values in an intense, in-depth, and comprehensive manner. Because of that, a suitable, precise, and effective integration model needs to be explored carefully.

\subsection{Research Purposes}

The purpose of this research is to explore conservation values that are most suitable for lectures that support the university's vision.

\subsection{Theoritical Review}

Several studies that discuss the development of a learning model concerning non-cognitive aspects, especially in soft skills and character, are often found in research on the psychology of the child, adolescent, and adult development. Research conducted by Sudana (2017) suggests that the soft skill aspect of the top category will color individual success in the world of work. Soft skills are a marker of the fundamental character of a person having positive behavior.

Research conducted by Supraptono (2018), which involved Bidikmisi students at UNNES, showed that soft skills training was proven to create positive attitudes towards students' productivity values in carrying out their academic life. They become aware of the meaning of a sense of responsibility as an educated group who must be role models for the environment, ready to carry out meaningful developmental tasks for life. In line with the research above, students' character building will be more effective if carried out through the internalization of fundamental values that, by design, are carried out carefully in every meaningful teaching material. Wangid (2015) emphasizes that it is possible to internalize the values of goodness for students more effectively by developing thematic specific subjects. The case discussion that affects an object shows that students are much more sensitive in developing themselves into individuals who are aware of social and environmental responsibility.

The research discussed above has a strong enough relationship and becomes the basis for the research. From this research, sufficient meaning can be drawn to formulate strategies, the latest methods that can be applied in the FT UNNES environment. This method aims to develop conservation values that are integrated into the lecture process of subject areas of study so that the output can be used as a benchmark for the success of the university's vision, namely the development of character strengths for the growth of science, art, culture and the development of the environment in harmony with national development and the international community.

\subsection{Priority of Research}

1) It has strategic value for universities that declare themselves universities that carry the vision of conservation and internationalization. 2) Research is in line with the efforts of higher education institutions to instill the values of innovation, creativity, honesty, environmental awareness as proclaimed by the Ministry of Research, Technology, and Higher Education in its long-term programs. 3) This research will contribute to the concepts of educational, scientific 
theories, particularly in terms of methodologies and learning strategies that integrate the dimensions of conservation values into the scientific disciplines of the field of study.

\section{Methodology}

\subsection{Research Critical Approach}

Starting from the primary research issue that prioritizes a model of integration of conservation values in subject areas of study, a closer perspective is the concept or perspective of models, learning strategies in universities with an orientation of learning outcomes. Thus, this study's critical approach is to use a phenomenological epistemological approach, which means that variables, methods, and interpreting research data will be studied based on the urgency and demands that develop in the research setting environment.

This research is a research with a quantitative approach, which measures the Integration of Conservation Values Model into the Field of Study at the Faculty of Engineering, Semarang State University.

\subsection{Data Source}

According to (Sukestiyarno, 2010) the source of the data generated is a source of data in the form of numbers or numbers where the data is the result of observations (questionnaires), numeration (calculations), and or measurements of a variable.

\subsection{Research Subject}

The subjects of this study were several students who had taken the general course (MKU) on Conservation Education. The population in this study is within the Faculty of Engineering, State University of Semarang. The determination of the sample size of the respondents refers to Jackob Nielsen (2012), who says that the user test for quantitative research is at least 20 respondents. In this study, the number of samples determined was as many as 60 students of the Faculty of Engineering, Semarang State University from various fields of study who had taken the Conservation Education MKU course.

\subsection{Data Collection Instruments and Techniques}

The instrument used in this study was a questionnaire sheet that was used to determine the reliability of the model. In contrast, the data collection technique in this study the writer used the distribution of instruments in the form of a questionnaire filled out by Faculty of Engineering, State University of Semarang students who had attended conservation courses.

\subsection{Test Data Validity or Test Validity and Reliability}

According to (Sugiyono, 2012), there are two kinds of validity: internal validity, and external validity. Internal validity relates to the degree of accuracy of the research design with the results to be achieved. Meanwhile, external validity relates to the degree of accuracy of 
whether the research results can be generalized or applied to the population where the sample is taken.

Validity and reliability testing, according to (Sugiyono, 2012) includes credibility (internal validity), transferability (external validity), dependability (reliability), and confirmability (objectivity). In this study, the author used triangulation credibility testing, namely checking data from various sources in various ways and at various times.

\subsection{Data Analysis Technique}

Following the type of data obtained and the problems and expected research objectives, the data collected was then analyzed. To analyze the data obtained using descriptive analysis techniques with percentage presentation. The category level of application of conservation values can be seen in Table1.

Table 1. Level Category of Conservation Values Application

\begin{tabular}{ccc}
\hline Values Application & Category & Percentage \\
\hline 1 & Lowest & $0 \%-20 \%$ \\
2 & Low & $21 \%-40 \%$ \\
3 & Moderate & $41 \%-60 \%$ \\
4 & High & $61 \%-80 \%$ \\
5 & Highest & $81 \%-100 \%$ \\
\hline
\end{tabular}

\subsection{Result}

Based on the data obtained, then the analysis is carried out, which is described as follows:

The frequency distribution and frequency percentages are obtained from the results of students' application responses to real activities of conservation character as in Table 2 below.

Table 2. Frequency Distribution of Student Application Levels on Conservation Character Activities

\begin{tabular}{|c|c|c|c|c|c|c|c|c|c|c|}
\hline \multirow[t]{2}{*}{ Instrument Items } & \multicolumn{2}{|c|}{$\begin{array}{c}\begin{array}{c}\text { The } \\
\text { lowest }\end{array} \\
\end{array}$} & \multicolumn{2}{|c|}{ Low } & \multicolumn{2}{|c|}{ Moderate } & \multicolumn{2}{|c|}{ High } & \multicolumn{2}{|c|}{ Highest } \\
\hline & $\mathrm{f}$ & $\%$ & f & $\%$ & $\mathbf{f}$ & $\%$ & f & $\%$ & $f$ & $\%$ \\
\hline $\begin{array}{l}\text { 1. I am determined to be a person } \\
\text { who benefits society }\end{array}$ & 0 & 0 & 0 & 0 & 0 & 0 & 8 & 13,3 & 52 & 86,7 \\
\hline $\begin{array}{l}\text { 2. Carrying out worship is the } \\
\text { main thing }\end{array}$ & 0 & 0 & 0 & 0 & 0 & 0 & 14 & 23,3 & 46 & 76,7 \\
\hline $\begin{array}{l}\text { 3. I put the best possible process in } \\
\text { order to achieve the best results }\end{array}$ & 0 & 0 & 0 & 0 & 0 & 0 & 23 & 38,3 & 37 & 61,7 \\
\hline $\begin{array}{l}\text { 4. Cheating is not considered a } \\
\text { responsible person }\end{array}$ & 0 & 0 & 0 & 0 & 6 & 10 & 26 & 43,3 & 28 & 46,7 \\
\hline $\begin{array}{l}\text { 5. I dare to pay dearly for the } \\
\text { status of goodness }\end{array}$ & 1 & 1,67 & 10 & 16,7 & 18 & 30 & 19 & 31,7 & 12 & 20 \\
\hline $\begin{array}{l}\text { 6. Helping and being ready to } \\
\text { sacrifice for others has become } \\
\text { my behavior }\end{array}$ & 0 & 0 & 0 & 0 & 0 & 0 & 13 & 21,7 & 47 & 78,3 \\
\hline
\end{tabular}


The frequency distribution of student application level to real activities of conservation character shows that the level of application is dominated by the "Highest" category as much as $62 \%$ and the "High" category by $28 \%$. The percentage of the highest application level in the "Highest" category is found in instrument items 1, 2, 3, 4, and 6. At the same time, the percentage of the highest application level in the "High" category is found in instrument item number 5. This data indicates that conservation values, which are contained in real activities of conservation character, are appropriate and can be applied in lectures in fields of study that support the university's vision.

From the results of student application responses to the internalization process of conservation learning, the frequency distribution and frequency percentages are obtained in Table 3 below.

Table 3. Frequency Distribution of Student Application Levels to the Internalization Process of Conservation Learning

\begin{tabular}{|c|c|c|c|c|c|c|c|c|c|c|}
\hline \multirow{2}{*}{ Instrument Items } & \multicolumn{2}{|c|}{$\begin{array}{c}\begin{array}{c}\text { The } \\
\text { lowest }\end{array} \\
\end{array}$} & \multicolumn{2}{|c|}{ Low } & \multicolumn{2}{|c|}{ Moderate } & \multicolumn{2}{|c|}{ High } & \multicolumn{2}{|c|}{ Highest } \\
\hline & $\mathbf{f}$ & $\%$ & f & $\%$ & $\mathrm{f}$ & $\%$ & $\mathbf{f}$ & $\%$ & $\mathbf{f}$ & $\%$ \\
\hline $\begin{array}{l}\text { 1. Conservation principles guide } \\
\text { my interactions on campus }\end{array}$ & 0 & 0 & 0 & 0 & 3 & 5 & 27 & 45 & 30 & 50 \\
\hline $\begin{array}{l}\text { 2. A culture of excellence is built } \\
\text { with personal awareness }\end{array}$ & 0 & 0 & 0 & 0 & 3 & 5 & 22 & 36,7 & 35 & 58,3 \\
\hline $\begin{array}{l}\text { 3. Students need to have ethical } \\
\text { integrity in achieving their } \\
\text { goals }\end{array}$ & 0 & 0 & 0 & 0 & 1 & 1,67 & 14 & 23,3 & 45 & 75 \\
\hline $\begin{array}{l}\text { 4. Students need to have ethical } \\
\text { integrity in achieving their } \\
\text { goals }\end{array}$ & 0 & 0 & 0 & 0 & 3 & 5 & 20 & 33,3 & 37 & 61,7 \\
\hline $\begin{array}{l}\text { 5. Maintaining and caring for } \\
\text { social cohesiveness is an } \\
\text { equally important and } \\
\text { fundamental task }\end{array}$ & 0 & 0 & 2 & 3,33 & 11 & 18,3 & 32 & 53,3 & 15 & 25 \\
\hline
\end{tabular}

The frequency distribution of student application level to the internalization process of conservation learning shows that the level of application is dominated by the "Highest" category by $54 \%$ and the "High" category by $38 \%$. The percentage of the highest application level in the "Highest" category is found in instrument items 1, 2, 3, and 4. In contrast, the percentage of the highest application level in the "High" category is found in instrument number 5. This data indicates that the conservation values contained in the process of internalizing conservation learning, appropriate and applicable in subject areas of study that support the vision of the university.

From the results of student application responses to lecture integration, the frequency distribution and frequency percentage are obtained as in Table 4 below. 
Table 4. Frequency Distribution of Student Application Levels on Lecture Integration

\begin{tabular}{|c|c|c|c|c|c|c|c|c|c|c|c|}
\hline & \multirow{2}{*}{ Instrument Items } & \multicolumn{2}{|c|}{$\begin{array}{c}\begin{array}{c}\text { The } \\
\text { lowest }\end{array} \\
\end{array}$} & \multicolumn{2}{|c|}{ Low } & \multicolumn{2}{|c|}{ Moderate } & \multicolumn{2}{|c|}{ High } & \multicolumn{2}{|c|}{ Highest } \\
\hline & & f & $\%$ & f & $\%$ & f & $\%$ & f & $\%$ & f & $\%$ \\
\hline 1. & $\begin{array}{l}\text { Conservation values can be } \\
\text { applied to group lectures in } \\
\text { the field of study }\end{array}$ & 0 & 0 & 0 & 0 & 2 & 33,3 & 27 & 45 & 31 & 51,7 \\
\hline 2. & $\begin{array}{l}\text { Material for the field of study } \\
\text { can be inserted with } \\
\text { conservation material at the } \\
\text { beginning of the lecture }\end{array}$ & 0 & 0 & 0 & 0 & 0 & 0 & 26 & 43,3 & 34 & 56,7 \\
\hline 3. & $\begin{array}{l}\text { Subjects in the field of study } \\
\text { that can be inserted into the } \\
\text { pillars of conservation are in } \\
\text { each semester }\end{array}$ & 0 & 0 & 0 & 0 & 2 & 33,3 & 23 & 38,3 & 35 & 58,3 \\
\hline 4. & $\begin{array}{l}\text { The number of courses is at } \\
\text { least } 2 \text { to } 4 \text { courses }\end{array}$ & 0 & 0 & 0 & 0 & 3 & 5 & 24 & 40 & 33 & 55 \\
\hline 5. & $\begin{array}{l}\text { The foundation of } \\
\text { conservation education is vital } \\
\text { for other subjects }\end{array}$ & 0 & 0 & 0 & 0 & 4 & 6,67 & 22 & 36,7 & 34 & 56,7 \\
\hline 6. & $\begin{array}{l}\text { Conservation value learning is } \\
\text { very supportive of forming } \\
\text { excellent graduate candidates }\end{array}$ & 0 & 0 & 0 & 0 & 7 & 11,7 & 23 & 38,3 & 30 & 50 \\
\hline
\end{tabular}

The frequency distribution of student application levels towards lecture integration shows that the level of application is dominated by the "Highest" category as much as $55 \%$ and the "High" category by $40 \%$. The percentage of the highest application level in the "Most High" category appears on all instrument items. This data shows that the conservation values contained in the integrity of the lecture are appropriate and can be applied in lectures in fields of study that support the vision of the university.

From the results of students' application responses to long-term vision, the frequency distribution and frequency percentage are obtained as in Table 5 below.

The frequency distribution of student application levels towards long-term vision shows that the "Highest" category dominates the level of application at $69 \%$ and the "High" category by $28 \%$. The percentage of the highest application level in the "Highest" category is found in instrument items $1,2,4,5$, and 6 . At the same time, the percentage of the highest application level in the "High" category is found in instrument item number 3. This data indicates that the values of conservation contained in the long-term vision is appropriate and can be applied in lectures in fields of study that support the vision of the university. 
Table 5. Frequency Distribution of Student Application Levels to Long-Term Vision

\begin{tabular}{|c|c|c|c|c|c|c|c|c|c|c|c|}
\hline & \multirow{2}{*}{ Instrument Items } & \multicolumn{2}{|c|}{$\begin{array}{c}\text { The } \\
\text { lowest }\end{array}$} & \multicolumn{2}{|c|}{ Low } & \multicolumn{2}{|c|}{ Moderate } & \multicolumn{2}{|c|}{ High } & \multicolumn{2}{|c|}{ Highest } \\
\hline & & f & $\%$ & $\mathbf{f}$ & $\%$ & $\mathbf{f}$ & $\%$ & $\mathbf{f}$ & $\%$ & $\mathbf{f}$ & $\%$ \\
\hline 1. & $\begin{array}{l}\text { The principle of developing } \\
\text { conservation values in line } \\
\text { with development needs }\end{array}$ & 0 & 0 & 0 & 0 & 2 & 33,3 & 20 & 33,3 & 38 & 63,3 \\
\hline 2. & $\begin{array}{l}\text { The development of moral } \\
\text { values is a necessity to build } \\
\text { superior human resources }\end{array}$ & 0 & 0 & 0 & 0 & 0 & 0 & 18 & 30 & 42 & 70 \\
\hline 3. & $\begin{array}{l}\text { The maintenance of art and } \\
\text { culture is the duty of the } \\
\text { student community in any } \\
\text { field }\end{array}$ & 0 & 0 & 0 & 0 & 8 & 13,3 & 26 & 43,3 & 26 & 43,3 \\
\hline 4. & $\begin{array}{l}\text { The sublime culture inherited } \\
\text { from its predecessors must be } \\
\text { adequately preserved }\end{array}$ & 0 & 0 & 0 & 0 & 0 & 0 & 13 & 21,7 & 47 & 78,3 \\
\hline . & $\begin{array}{l}\text { Natural resources need to be } \\
\text { preserved as the capital for } \\
\text { sustainable development }\end{array}$ & 0 & 0 & 0 & 0 & 0 & 0 & 5 & 8,33 & 55 & 91,7 \\
\hline 6. & $\begin{array}{l}\text { For UNNES, the } \\
\text { internalization of conservation } \\
\text { values is a strategic vision } \\
\text { needed for long-term } \\
\text { development }\end{array}$ & 0 & 0 & 0 & 0 & 1 & 1,67 & 20 & 33,3 & 39 & 65 \\
\hline
\end{tabular}

\section{Discussion}

Following the 2017 RENIP UNNES that in the future, conservation learning will become a superior university program in line with the development of superior character values, noble arts and culture, natural resource management, and a wise environment to create future national leaders. On the other hand, it is based on research that conservation insights allow giving direction and guiding attitudes and behaviors that are responsible, polite, and understand the meaning of sustainable development (Saratri, 2016).

Suppose we examine the intention of students concerning real activities related to the character of conservation. In that case, it can be found that personal development, which has conservation value, is closely related to the commitment that is beneficial to society, the belief that carrying out conservation is part of worship, prioritizing the best possible process to achieve the best result. On the other hand, he refuses to cheat and is brave enough to pay dearly for his dignity, ready to sacrifice to help others. This description is a personal picture of the superior character of students as an impact of the process of planting conservation values through lectures. 
In the context of the relationship between individuals and the community, conservation principles are found to be guidelines, raise personal awareness towards a culture of excellence, form integrity in achieving future goals, have creative, innovative principles and care for social cohesiveness. This condition is in line with research about students' moral and real behavior on campus (Sarlito Wirawan, 2002).

The application of conservation values as a result of integration in lectures is possible to be applied through lectures in groups of subject areas, at the time of introductory lectures, in general subjects and subject areas of study. Concerning the long-term vision, students who realize and understand that the principle of developing conservation values is a personal need, are believed to be able to build superior human resources in the future, develop a high culture, and develop long-term development vision. The conservation value integration model that can be developed in this research is through lectures in the field of study, through learning general subjects, through real work lecture activities, practical field experiences, through laboratory practicum learning. The completeness that needs attention is the development of RPS per the spirit of conservation values, benefits, and the accuracy of the learning process. Teaching materials that have a significant contribution to conservation behavior, both through digital sources and other sources, can be used by students.

Lecture strategies that can be carried out are FGD (Focus Group Discussion), field visits, student activity portfolios, completion of projects that contain real benefits.

To be able to find out the conservation value that has been received by students, it is necessary to measure the authentic evaluation. What is meant by authentic evaluation is a direct measurement of real behavior or real activities. Through an authentic evaluation process, lecturers can measure the impact of integration conservation learning into lectures in the field of study within the engineering faculty. Through subject areas of study, conservation learning has a meaning that is in line with the learning process in higher education.

\subsection{Output Reached}

Starting from the research results, the results of this study resulted in a concept of integrated conservation value models in lectures through the preparation of conservation-based RPS, teaching materials that have conservation content, lecture strategies, evaluation techniques, and continued with extra-curricular activities that are related to the material. -the material of the field of study by their respective disciplines. See Figure 1. 


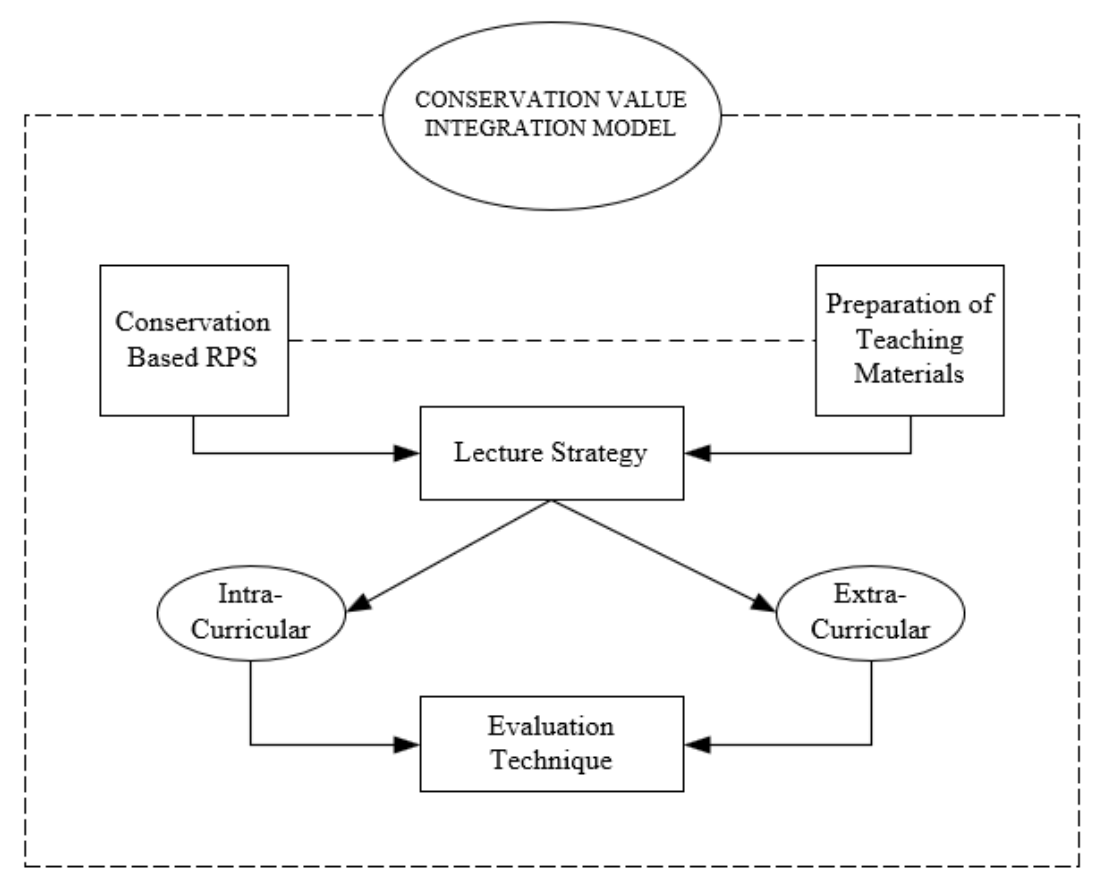

Fig. 1. Concept of Conservation Value Integration Model in Lectures.

\section{Conclusion}

Based on the data analysis that has been described, the research conclusions can be drawn; 1). Conservation values contained in real activities of conservation character, the process of internalizing conservation learning, lecture integration, and long-term vision can be applied in lectures in fields of study that support the university's vision. 2). Conservation values that are most suitable for lectures in the field of study that support the university's vision are the application of a long-term vision.

Suggestion. 1). Conservation values contained in real activities of conservation character, the internalization process of conservation learning, lecture integration, and long-term vision can be used as references in developing curriculum and learning tools in subject areas of study. 2) Conservation values applied in field subjects studies should be well instilled in all students to support the university's vision. 


\section{References}

[1] Amin Retnoningsih. 2018. Pendidikan Konservai Tiga Pilar. Penerbit UNNES Press: Semarang

[2] Badan Pengembangan Konservasi (Bangvasi) Unnes. 2015. Panduan Nilai Konservasi, Karakter Konservasi, Pilar Konservasi, dan Perilaku Konservasi. Seamrang: Universitas Negeri Semarang

[3] Bertens, K. 2001. Etika. Jakarta: PT. Gramedia Pustaka Utama

[4] Darsono, Valentinus. 1995. Pengantar Ilmu Lingkungan. Yogyakarta : Penerbitan Universitas Atma Jaya.

[5] Effendi, M.R. 2009. Dasar-Dasar Konservasi Sumber Daya Alam Hayati dan Ekosistemnya. Materi disampaikan pada Pembentukan Kader Konservasi BTNGC

[6] Supraptono, Eko, 2018. Pelatihan dan Training Soft Skill bagi Persiapan Karir Mahasiswa Bidikmisi UNNES. Pusat Karir dan BK UNNES : Semarang

[7] Ganter, Grace, and Margaret Yeakel. 1980. Human Behavior and The Social Environment a Perspective for Social Work Practice. New York. Columbia University Press

[8] Handoyo, Eko dan Tijan. 2010. Model Pendidikan Karakter berbasis Konservasi: Pengalaman Universitas Negeri Semarang. Semarang: Cipta Prima Nusantara

[9] Hardati, Puji, Dewi Liesnoor Setyowati Saratri WIlonoyudho., Nana Kariada, Asep Purwo Yudi Utomo. 2016. Pendidikan Konservasi. Semarang: UNNES Press

[10] Sudana, I Made, 2017., Pengembangan Model Pembelajaran Soft Skill pada Siswa SMK di Kota Semarang, Disertasi, tidak diterbitkan PPs UNNES : Semarang

[11] LIPI [Lembaga Ilmu Pengetahuan Indonesia]. 2014. Kekinian Keanekaragaman Hayati Indonesia. Kerjasama kementrian PPN/BAPPENAS, KLHK, LIPI, LIPI Press, BOGOR

[12] Qudus, Nur., dkk. 2016. Pilar Kreativitas Universitas Konservasi. Buku Panduan. Universitas Negeri Semarang.

[13] Wirawan, Sarlito., 2002. Nilai2 dasar manusia dlm tugas perkembangan, Erlangga, Jakarta. 